\title{
Koncentračná zásada vs. zásada náležitého zist'ovania skutkového stavu veci v slovenskom trestnom konaní
}

\author{
Principle of Concentration vs. Principle of Investigation \\ the Facts Beyond Reasonable Doubts in Slovak Criminal Law
}

\author{
Sergej Romža ${ }^{*}$
}

\begin{abstract}
Abstrakt
Koncentračná zásada vo všeobecnosti, nastoliuje požiadavku, aby určité procesné úkony, procesné strany realizovali (uplatnili) - skoncentrovali v urüitom procesnom štádiu a dokonca do určitébo procesného momentu, k.torý mô̌̌e byt' naviazaný na rôzne procesné skutočnosti.

Koncentračná zásada, osobitne nadobúda na význame, vo vžt’abu k. procesu dokazovania, ked' zákonodarca $v$ tejto súvislosti ustanovije cáasový cenzus, teda dokedy mỗzu procesné strany navrbovat', resp. predkladat' dôkary. Pre spráune pochopenie podstaty koncentračnej zásady, jej miesta a uplatnenia v trestom konaní, javí sa nevyhnutným objasnit' jej súvż’ažnost' $k$ iným referenčným zásadám trestnébo konania a v tejto súvislosti osobitne k zásade náležitébo zistenia skutkového stavu veci. Pri súčasnej koncepcii kreovania a bierarchie základných zásad trestnébo konania, žiada sa poznamenat', že zákonodarca priznáva zásade náležitébo zistenia skutkovébo stavu veci privilegovaný status.
\end{abstract}

Klíčová slova

Koncentračná zásada; zásada nálę̧itého zistenia skutkovébo stavu veci; zásada koncentračná; zásada rovnosti procesných strán; dokazovanie; dôkazné prostriedky; navrhovanie dôkazov; princípy v trestnom konanim blavné pojednávanie; procesné strany.

\begin{abstract}
The principle of concentration in general raises the requirement that certain procedural acts, process parties be implemented (concentrated) at a certain stage of the proceedings and even a certain procedural moment, which may be linked to different procedural facts. The principle of concentration, in particular, acquires the meaning, in relation to the evidentiary process, when the legislator establishes a census in this respect, when the parties may propose or, to provide evidence. In order to properly understand the merits of the principle of concentration, its place and its application in criminal proceedings, it is necessary to clarify its compatibility with other reference principles of criminal procedure and, in that regard, specifically with the principle of investigation the facts beyond reasonable doubts. With the current concept of creation and the hierarchy of the basic principles of criminal proceedings, it is to be noted that the legislator recognizes the privileged status of principle of investigation the facts beyond reasonable doubts.
\end{abstract}

\footnotetext{
Doc. JUDr. Sergej Romža, PhD., Katedra trestného práva, Univerzita Pavla Jozefa Šafárika v Košiciach, Slovensko / Department of Criminal Law, Pavol Jozef Šafárik University in Košice, Slovak Republic / E-mail: sergej.romza@upjs.sk
} 


\section{Keywords}

Principle of Concentration; Principle of Investigation the Facts Beyond Reasonable Doubts; Principle of Equality of Parties; Evidence; Evidentiary Process; Means of Evidentiary Process; Principles in Criminal Proceedings; Trial; Procedural Parties.

\section{Úvod}

Koncentračná zásada je vlastná predovšetkým civilnému sporovému konaniu, kde jej zákonodarca priznáva status základnej zásady.

Implementácia koncentračnej zásady do štruktúry trestného konania, do štruktúry jednotlivých procesných inštitútov, je len logickým dôsledkom kodifikácie zásady kontradiktórnosti v Trestnom poriadku, s ktorou je ideovo - vecne previazaná.

Zároveň sa žiada pripomenút', že implementácia koncentračnej zásady do štruktúry trestného konania organicky súvisí s posilňovaním aktívnej participácie procesných práv, ktoré im priznáva Trestný poriadok.

V súvislosti s koncentračnou zásadou, môžeme skôr hovorit’ o implementácii jej jednotlivých atribútov do štruktúry trestného konania a osobitne do štruktúry jednotlivých procesných inštitútov, ako o implementácii zásady samotnej.

Napriek uvedenému ide o tendenciu, ktorá by mala de lege ferenda progredovat' zásadným d’alším atribútom tejto zásady, s ambíciou jej kreovania ako základnej zásady trestného konania.

\section{Vymedzenie podstaty, účelu a funkcie princípov a zásad $\mathrm{v}$ trestnom konaní}

Pre tvorbu a realizáciu práva, v jeho hmotnej aj procesnej zložke, sú príznačné určité princípy, resp. zásady, podla ktorých a na základe ktorých, sa tvorba a realizácia práva ako významného spoločenského fenoménu, uskutočňuje. ${ }^{1}$

Každé právne odvetvie je ovládané určitými princípmi a zásadami. Tieto princípy, resp. zásady, charakterizujú základ práva i jeho obsah, premietajú sa nielen do právotvornej činnosti, ale aj do roviny realizovanej interpretačnej a právno - aplikačnej. V právnej vede sú považované za abstraktné právne pravidlá, ktoré majú rozdielny charakter. ${ }^{2}$

Existencia princípov v práve je nevyhnutná. Princípy vyjadrujú nemennost' určitého spoločenského javu. Táto nemennost' neovplyvňuje to, či je upravený právnymi normami alebo nie, prípadne v akom právnom rámci, ani v akej forme je daný spoločenský fenomén právne vyjadrený, a nevplýva na ňu ani stabilita, či nestabilita spoločenských vzt'ahov.

1 BABJAK, J. Daňové právo na Slovensku. Bratislava: EPOS, 2015, s. 422.

2 HARVÁNEK, J a kol. Právní teórie. Brno: Iuridica Brunensia, 1995, s. 234. 
Dôvodom pre existenciu zásad, či princípov v každom právnom odvetví, je najmä charakter právnych noriem ako všeobecných pravidiel správania sa.

Trestný poriadok tvorí ucelenú sústavu. Jeho štruktúra a systém zabezpečujú funkčnost' trestného procesu. Toto zabezpečenie je vel'mi zložité, a aby tento systém mohol fungovat', sú stanovené presné právno - politické princípy, na ktorých je tento proces vybudovaný. ${ }^{3}$

Význam základných zásad a princípov vyplýva z toho, že sú základom, na ktorom spočiva trestné právo procesné. Ich uplatnenie v trestnom konaní je nevyhnutným predpokladom, najdôležitejšou zárukou skutočne účinného prostriedku plnenia úloh nášho trestného konania nakol'ko práve ony v ňom zaručujú dodržiavanie zmyslu zákona, zabezpečujú dôslednú ochranu tak spoločnosti, ako aj práv a oprávnených záujmov občanov, predovšetkým osoby, voči ktorej sa vedie trestné konanie. Bez znalosti týchto zásad a princípov nemožno pochopit' podstatu nášho trestného konania, význam všetkých jeho inštitútov a štádií, nemožno porozumiet' jednotlivým ustanoveniam Trestného poriadku a správne ich aplikovat' v praxi, nakol'ko sú základným vodítkom pre výklad. Bez správneho stanovenia základných zásad a princípov a ich znalosti, nie je možná legislatívna práca v oblasti trestného konania, nakol'ko právna úprava všetkých ustanovení Trestného poriadku, z nich musí vychádzat' a samozrejme nie je možná ani akákol'vek vedecká práca v odbore trestného práva. ${ }^{4}$

Na základe uvedeného možno v koncentrovanej forme vymedzit' nasledovné funkcie, resp. význam základných zásad a princípov:

a) poznávací;

b) interpretačný;

c) aplikačný;

d) normotvorný.

ad a) poznávací význam základných zásad a princípov spočíva $\mathrm{v}$ tom, že bez pochopenia ich významu nemožno porozumiet' jednotlivým inštitútom a ustanoveniam Trestného poriadku.

ad b) základné zásady a princípy tvoria základné vodítko, základnú orientáciu pre výklad zákonov orgánmi činnými v trestnom konaní a súdmi. Osobitne uvedené platí v prípade absencie explicitnej normatívnej úpravy jednotlivých procesných inštitútov, či procesných práv a povinností subjektov trestného konania. Žiada sa osobitne akcentovat',

3 GŘIVNA, T. Základní zásady v připravované rekodifikaci trestního řízení z komparatívniho pohledu; In: Principy a zásady v trestnom práve; Zborník príspevkov z. medzinárodnej vedeckej konferencie. Košice: Univerzita P. J. Šafárika v Košiciach, Právnická fakulta, 2016, s. 59. ISBN 978-80-8152-223-9.

4 CÍSAŘOVÁ, D., J. FENYK, T. GŘIVNA a kol. Trestníprávo procesní. 5. vyd. Praha: ASPI, 2008, s. 63-64; rovnako porov. ŠÁMAL, P., J. MUSIL, J. KUCHTA a kol. Trestní právo procesní. 4. vyd. Praha: C. H. Beck; 2013, s. 86 a nasl.; Rovnako porov. JELÍNEK, J. a kol. Trestni právo procesní; 3. vyd. Praha: Leges, 2013, s. 132 a nasl. 
že výklad jednotlivých princípov a zásad, musí smerovat’ k naplneniu základného účelu trestného konania, normatívne vymedzeného v ust. $\int 1$ 'Trestného poriadku a musí byt' ústavne konformný.

ad c) aplikačný význam základných princípov a zásad spočíva $\mathrm{v}$ tom, že predstavujú dôležité vodítko (smernicu) pre aplikáciu pri riešení konkrétnych sporných otázok trestného konania.

ad d) normotvorný význam základných princípov a zásad sa odvíja od skutočnosti, že akýkol’vek posun v spoločenských vzt’ahoch (najmä v sociálnej oblasti, vo faktoroch, ktoré ovplyvňujú kriminalitu), vytvára totiž tlak a požiadavky na zmenu zákonov v trestnoprávnej oblasti, ale aj naopak, zmenené zákony, spätne pôsobia na posun v chápaní základných princípov a zásad. Rovnako význam základných princípov a zásad pre tvorbu práva, spočíva v tom, že novo zavádzané procesné inštitúty, nemajú kolidovat's existujúcimi zásadami trestného konania, resp. že je nevyhnutné skúmat', či doterajšie základné zásady trestného konania vyhovujú, a teda, či nie je žiaduca ich zmena. ${ }^{5}$

Platí totiž základná premisa, že všetky základné princípy a zásady musia vo svojom súhrne vytvárat' vnútorne (ideovo) konzistentný celok, v opačnom prípade pôsobia na systém trestného konania deštruktívne.

Pojem právny princíp, právna zásada, ale aj súvisiace pojmy, ako je právna norma, pravidlo, maxima, či paradigma, nie sú v právnej teórii interpretované jednotne, naopak sú predmetom intenzívnych a častokrát antagonistických argumentácii. ${ }^{6}$

Súčasná jurisprudencia vel’mi často oba pojmy, teda pojem, princíp a zásada, stotožňujú, či zamieňajú, resp. ich považujú za pojmy synonymné, s čím nemožno bez výhrad súhlasit'. Nazdávam sa, že najkomplexnejšie a v koncentrovanej forme, vymedzil podstatu pojmu právny princíp A. GERLOCH, ako „najušeobecnejšie pravidlá správania, ako regulatívne idey, k.toré v normativnej podobe vyjadrujú všeobecné ciele práva, ktorými sú základné hodnoty. ${ }^{67}$ Tradične zaužívaným chápaním pojmu princíp je definícia prezentovaná J. BOGUSZAKOM, ako „pravidlo relativne vysokého stupña všeobecnosti, ktoré nie je explicitne alebo implicitne vyjadrené alebo ako communis opinio doctorum, imanentné danému právu, právnemu odvetviu alebo právnemu inštitútu. Sú spoločné právu rôznych krajín, prinajmenšom v dosabu daného typu právnej kultúry. Obvykle

5 IVOR, J. a kol. Trestné právo procesné. 2. doplnené a prepracované vyd. Bratislava: IURA Edition, 2010, s. 54-55; Rovnako porov. ŠIMOVČEK, I. a kol. Trestné právo procesné. 2. rozšírené vyd. Plzeň: vydavatelství a nakladatelství Aleš Čeněk, s. r. o., s. 37-39; Rovnako porov. JELÍNEK, J. a kol. Trestníprávo procesní. 3. vyd. Praha: LEGES, 2013, s. 62-63.

6 Porov. WINTR, I. Řšse principir. Obecní a odvětvové princípy současného českého práva. Praha: Karolinum, 2006; BOGUSZAK, J. a kol. Právní principy. Pelhřimov: Vydavatelství 999, 1999; TRYZNA, J. Právní principy a právni argumentace. Praha: Auditorium, 2010.

7 GERLOCH, A. Princip právni jistoty v soudobém právu. In: BOGUSZAK, J. a kol. Právní principy. Pelhřimov, Vydavatelství 999, 1999, s. 77. 
nestrácajú platnost'v priebehu żmien, drubých konkrétnejšich právnych noriem, s ktorými sú späté pri aplikéciii".

Podl'a J. HARVÁNKA ,zatial', čo právne princípy sú základnými a nemenitelnými postulátmi, právne zásady sú menitel’númi postulátmi a majú menšiu mieru v̌̌eobecnosti"."

Významný predstavitel’ slovenskej jurisprudencie J. PRUSÁK, prezentuje právne princípy, ako „právne normy s najuyššn mierou abstrakcie, ktoré určuju aplikáciu, t.j. aj subsumpciu a interpretáciu práunych odvetví, zákonnikov, zákonov a jednotlivých častí právnych predpisov" ${ }^{10}$

$\mathrm{V}$ konečnom dôsledku nemožno opomenút' ani pragmatické vymedzenie podstaty pojmu právny princíp M. GAŠPAROM, ktorý princíp považuje (charakterizuje), „ako vedúcu prárnu ideu, ktorá platí bezo zvyškeu, nepripúst’a výnimku a má preto absolútne určenie ".11

Podl'a M. GAŠPARA „zásada, resp. jednotlivé základné zásady, sú skôr viazané na konkrétnost' spoločenských javov a vąt'ahov, ich poznatel'nost', relativnu stabilitu v aplikácii, pripúst'anie výnimiek zo svojho uplatñovania a pod." 12

Základné zásady trestného konania sú vedúce právne idey. ${ }^{13} \mathrm{Nad}$ rámec prezentovaného vymedzenia podstaty zásad trestného konania J. IVOR, akcentuje normatívny aspekt $\mathrm{v}$ ich charakteristike - vymedzení, ked’ dodáva, že „toto postavenie (postavenie vedúcich právnych idey) im musí priznat’ zákon“. ${ }^{14}$ Zároveň dodáva, že na základných zásadách je vybudovaný celý trestný proces, celá organizácia trestného konania, rozdelenie funkcii v trestnom konaní, teda aj všetky systémové a štrukturálne trestnoprocesné vzt'ahy.

J. JELÍNEK, zároveň pripomína, že základné zásady „sú prejavom právno - politickébo a právno - filozofického prístupu k trestnému konaniu, pričom v konečnom dôsledku vyjadrujú mienku zákonodarcu o najúčlnejšom usporiadani trestnébo procesu. “15

\section{Spôsob a rozsah normatívneho vyjadrenia základných zásad trestného konania v Trestnom poriadku}

Kodifikovanie základných zásad trestného konania, priamo do textu Trestného poriadku, dokonca zo systematického hl'adiska do textu jeho úvodných ustanovení, bolo vyvolané objektívnou potrebou, ktorá vyplývala z negatívnych skúseností v 50. rokoch 20.

8 BOGUSZAK, J. Pojetí, druhy a význam právnich princípů. In: Právny obæor, 2003, č. 3, s. 241.

9 HARVÁNEK, J. a kol. Teórie práva. Plzeň: Vydavatelství a nakladatelství Aleš Čeněk, s. r. o., 2008, s. 283.

10 PRUSÁK, J. Právne princípy a premene slovenského práva. Právny obzor, 2003, č. 3, s. 266.

11 GAŠPAR, M. a kol. Ceskoslovenské správne právo. Bratislava: Obzor, 1973, s. 122.

12 Ibid., s. 123.

13 ŠÁMAL, P. Základní zásady trestního ř́zení v demokratickém systému. Praha: CODEX, 1999, s. 44; Rovnako porov. JELÍNEK, J. a kol. Trestni právo procesní. 3. vyd. Praha: LEGES, 2013, s. 61.

14 IVOR, J. a kol. Trestné právo procesné. 2. doplnené a prepracované vyd. Bratislava: IURA Edition, 2010, s. 54.

15 JELÍNEK, J. a kol. Trestni právo procesní. 3. vyd. Praha: LEGES, 2013, s. 61. 
storočia. Kedy tieto základné zásady bolo potrebné identifikovat' z textu jednotlivých trestnoprocesných inštitútov, z obsahu jednotlivých procesných ustanovení, čo nevyhnutne viedlo k nejednoznačnosti v ich interpretácii a aplikácii.

Po prvý krát u nás boli základné zásady trestného konania kodifikované v úvodných ustanoveniach, v Trestnom poriadku r. 1961 (z. č. 141/1961 Zb.)

Avizované riešenia normatívnej reglementácie základných zásad trestného konania, a to explicitne v texte zákona, nie je jediným ani výlučným riešením.

Teoreticky do úvahy prichádzajú viaceré riešenia:

1. základné zásady trestného konania, normatívne vyjadrit' len $\mathrm{v}$ preambule, resp. v úvodných ustanoveniach, bez ich definície (zásady sa uplatňujú vždy prostredníctvom rôznych ustanovení, nie však priamo);

2. základné zásady sú normatívne vyjadrené iba v základných článkoch úvodnej časti zákona ako maximy (formulácia, by mala byt' stručná, jasná a jednoznačná), pričom by mali byt' aplikované iba prostredníctvom ustanovení zákona, nie však priamo, pričom ich význam by spočíval predovšetkým v legislatívnej a interpretačnej funkcii (pri tomto vymedzení, by mal byt' upravený katalóg zásad tak, aby boli vymedzené len najdôležitejšie zásady všeobecnej povahy, ktoré sa premietajú spravidla do celého trestného konania, zatial', čo ostatné zásady, ktoré sú v skutočnosti „priamymi“ právnymi predpismi - napr. vyhl’adávacia zásada, zásada bezprostrednosti a ústnosti, zásada vol’ného hodnotenia dôkazov, by boli vložené do konkrétnej právnej úpravy dokazovania alebo iných procesných postupov.

3. zásady, ktoré sú v teórii a praxi, všeobecne uznávané, neboli by priamo definované v Trestnom poriadku, ale boli iba vyjadrené v celkovej koncepcii Trestného poriadku a vo vymedzení jednotlivých ustanovení Trestného poriadku. ${ }^{16}$

Optimálnym riešením - koncepciou normatívneho vyjadrenia základných zásad v Trestnom poriadku, sa javí alternatíva 2 , ku ktorej sa prikláňa väčšina zástupcov náuky trestného práva procesného. ${ }^{17}$

Prezentované alternatívy možného legislatívno - technického vyjadrenia jednotlivých zásad trestného konania v Trestnom poriadku sa javí podstatnými, vo vzt’ahu k právnym úvahám o možnom spôsobe a rozsahu legislatívno - technického vyjadrenia v Trestnom poriadku, aj vo vzt'ahu ku koncentračnej zásade trestného konania.

16 GŘIVNA, T. Základní zásady v připravované rekodifikaci trestního řízení z komparatívniho pohledu; In: Principy a zásady v trestnom práve; Zbornik príspevkov z medzinárodnej vedeckej konferencie. Košice: Univerzita P. J. Šafárika v Košiciach, Právnická fakulta, 2016, s. 60-61.

17 Porov. KRATOCHVÍL, V. Základní zásady trestního řízení / trestního práva procesního v česko rakousko - polsko - euróvpskem srovnání. In: VANDUCHOVÁ, M. a T. GŘIVNA. Rekodifikace trestního práva procesníbo (aktuálni problémy). Praha: UK v Praze, 2008, s. 72. 


\section{K podstate, ciel'om a účelu koncentračnej zásady $\mathrm{v}$ trestnom konaní}

Koncentračná zásada je výnimkou zo zásady jednotnosti konania, je protipólom zásady jednotnosti konania.

Koncentračná zásada ako výnimka, musí byt' v zákone aj explicitne upravená. Iba s použitím toho prístupu možno potom identifikovat', že ide o výnimku. Naviac aplikácia koncentračnej zásady znamená zánik jedného zo základných procesných práv subjektov trestného konania - práva označovat' a predkladat' dôkazy po celú dobu konania. Zánik takéhoto procesného práva môže byt' upravený iba zákonom a to explicitne.

Zásada jednotnosti konania, vyjadruje právo subjektov trestného konania navrhovat' (predkladat') dôkazy a realizovat' procesné návrhy a oprávnenia po celú dobu konania, vrátane odvolacieho konania.

Naproti tomu, koncentračná zásada, sústred’uje (koncentruje) procesnú možnost' označovat' a predkladat' dôkazy, iba do určitého štádia konania, či procesného termínu a súčasne vylučuje túto možnost’ v ostatných štádiách konania.

Koncentračná zásada vyjadruje (stanovuje) časový cenzus, t.j. do akej doby môžu jednotlivé subjekty trestného konania navrhovat' a predkladat' dôkazy na podporu a preukázanie svojich skutkových tvrdení.

Účelom koncentračnej zásady je zamedzit' neustálemu a účelovému generovaniu d'alších procesných návrhov na vykonanie (doplnenie) dokazovania, ktoré by vo svojich dôsledkoch zakladali nedôvodné priet’ahy $\mathrm{v}$ prejednávaní trestnej veci, a teda by zakladali porušenie zásady rýchlosti a hospodárnosti trestného konania, ako aj porušenie práva na spravodlivé súdne konanie, garantované v čl. 6 ods. 1 Dohovoru o ochrane l’udských práv a základných slobôd.

Ciel’om koncentračnej zásady je „donútit"“ procesné subjekty, vyčerpat' všetky procesné dôkazné prostriedky, určené k ochrane ich procesných práv, ktorými tieto subjekty disponovali v určitom procesnom štádiu - fáze trestného konania.

Oprávnenie procesných subjektov, navrhovat' a predkladat' dôkazy kedykol'vek počas trestného konania (zásada jednotnosti konania), musí mat' však určité limity, najmä s prihliadnutím na už avizovanú efektívnost', rýchlost' a hospodárnost' konania, a rovnako tak na motiváciu jednotlivých subjektov k väčšej procesnej aktivite.

Z prezentovaného vymedzenia podstaty, účelu a ciel’a tak zásady jednotnosti konania, ako aj koncentračnej zásady, vyplýva, že tieto sa svojimi účinkami vzt’ahujú na procesnú činnost' vo forme dokazovania.

Vo všeobecnosti koncentračná zásada sa môže uplatňovat' v dvoch formách, ako:

- sudcovská koncentrácia konania (ako vhodná koncentrácia);

- zákonná koncentrácia konania (ako nutná koncentrácia);

Sudcovská koncentrácia je vo výlučnej diskrečnej právomoci súdu. 
Účelom sudcovskej koncentrácii konania, je zabránit’ tomu, aby procesné strany, spôsobovali priet’ahy v konaní, neskoro prezentovanými procesnými úkonmi, osobitne uvedené platí vo vzt'ahu k priebehu dokazovania. Napr. nie je žiadúce, aby procesné strany predkladali návrhy na vykonanie dokazovania až na hlavnom pojednávaní, čo by vo svojich dôsledkoch mohlo viest' $\mathrm{k}$ zmareniu účelu už nariadeného pojednávania a nutnost' odročenia, či vytýčenia iného termínu hlavného pojednávania. Samozrejme, nie je vylúčené, že predloženie návrhu na vykonanie (doplnenie) dokazovania, vyvstane až v priebehu hlavného pojednávania ako celkom prirodzená procesná reakcia na nové skutočnosti, ktoré vyšli najavo priebehu hlavného pojednávania.

Podstata sudcovskej koncentrácie spočíva v tom, že rozhodnutie o tom, či v konkrétnom prípade prezentovanie procesného návrhu na vykonanie (doplnenie) dokazovania na hlavnom pojednávaní, procesnou stranou, možno považovat' za účelovú procesnú obštrukciu je výlučne na subjektívnej úvahe konajúceho súdu. Jednoducho je vecou autonómnej úvahy konajúceho súdu, či v konkrétnom prípade, uplatní procesné konzekvencie (procesnú sankciu) voči procesnej strane, ktorá si nesplnila svoju procesnú povinnost' riadne a včas predložit', resp. označit' dôkazy. Prijaté procesné konzekvencie (sankcie) môžu spočívat' bud' $\mathrm{v}$ tom, že konajúci súd odmietne vykonat' takto oneskorene prezentovaný dôkazný návrh alebo uloží dotknutej procesnej strane poriadkové opatrenie, vo forme primeranej poriadkovej pokuty.

Uplatnenie diskrečného práva súdu, závisí od okolností konkrétneho prípadu. Oneskorené predloženie procesného návrhu na vykonanie dôkazov, môže súd ospravedlnit' na základe objektívnych kritérii (napr. právna zložitost' skutku - zložitost', resp. neurčitost' právnej kvalifikácie skutku) alebo subjektívnych kritérií (napr. schopnost’ procesnej strany rozpoznat' potrebu tvrdit' určité skutočnosti).

Zákonná koncentrácia konania, znamená, že procesné úkony procesných strán, ktoré podliehajú koncentrácii konania, nespôsobujú (nezakladajú) ex lege procesnoprávne účinky(súd na ne neprihliada), ak sú uplatnené po vyhlásení uznesenia, ktorým sa dokazovanie končí.

V trestnom konaní sa zákonná koncentrácia, neuplatňuje absolútne, ale modifikovane, ked' zákonodarca priznáva súdu možnost' rozhodnút' o doplnení dokazovania v prípade ak z obsahu prezentovanej záverečnej reči vyplynie potreba objasnit’ niektorú skutkovú okolnost'. V takomto prípade súd môže uznesením rozhodnút' (autonómne), že dokazovanie bude doplnené (porov. \276 ods. 1 zák. č. 301/2005 Z.z., Trestný poriadok, v znení neskorších predpisov, d’alej len ako „Tr. por.“).

Zásada jednotnosti konania nie je $\mathrm{v}$ našom Trestnom poriadku explicitne normatívne vyjadrená, avšak jednotlivé jej atribúty, prvky, možno identifikovat' tak v konštrukcii (obsahu) jednotlivých zásad trestného konania, ktoré vo svojom súhrne možno klasifikovat' ako zásady dokazovania, ako aj v obsahu d’alších základných zásad, ako je zásada 
práva na obhajobu, či zásada kontradiktórnosti. Zároveň jednotlivé atribúty, prvky zásady jednotnosti konania, možno spol’ahlivo identifikovat' aj v obsahu jednotlivých procesných inštitútov.

Koncentračnú zásadu, resp. jej prvky - atribúty, spol’ahlivo možno identifikovat' v ust. \240 ods. 3-5 Trestného poriadku, marginálne označeného ako „doručenie obžaloby“. Ust. \ 240 ods. 3 Trestného poriadku, explicitne ukladá konajúcemu súdu, spolu s rovnopisom obžaloby, osobám uvedeným v ods. 1, doručit' aj výzvu, aby bez meškania oznámili súdu a osobám a ostaným stranám, návrhy na vykonanie dôkazov. Zároveň predmetné ustanovenie ukladá konajúcemu súdu povinnost', v predmetnej výzve, upozornit' dotknuté subjekty na to, že vykonanie neskôr navrhnutých dôkazov, ktoré stranám boli známe v čase doručenia výzvy, môže súd odmietnut'.

Z obsahu predmetného ustanovenia \ 240 ods. 3 Trestného poriadku, vyplýva pre konajúci súd nielen obligatórna povinnost' doručovat' procesným stranám, ktorých okruh je vymedzený explicitne, v ust. \240 ods. 1 Trestného poriadku, procesnú výzvu, aby oznámili súdu a ostatným procesným stranám, svoje návrhy na vykonanie dôkazov na hlavnom pojednávaní, ale rovnako tak povinnost' konajúceho súdu, určit' procesným stranám primeranú lehotu, ktorá je v aplikačnej praxi obvykle 10-dňová, v ktorej majú oznámit’ svoje návrhy na vykonanie dôkazov.

Zákonodarca, v predmetnom ustanovení stanovil časový cenzus - dobu do kedy môžu procesné strany navrhovat' a predkladat' dôkazy, ktoré sa majú vykonat' na hlavnom pojednávaní. Nepochybne ide o výnimku, redukciu práva procesných strán predkladat' dôkazy kedykol’vek v priebehu trestného konania, teda ide o formu zákonného vyjadrenia jedného z atribútov koncentračnej zásady.

Nemenej podstatným sa v tejto súvislosti javí, aj normatívne vymedzenie (ukotvenie) procesných následkov - účinkov, ktoré zákonodarca spája s nerealizovaním priznaného procesného práva procesnými stranami, v ustanovenej (primeranej) lehote, určenej konajúcim súdom, v zaslanej výzve, ked’ pre tento prípad ustanovuje procesné konzekvencie, vo forme možnosti konajúceho súdu odmietnut' vykonanie neskôr navrhnutých, resp. predložených dôkazov, procesnými stranami.

Osobitný procesný režim, zákonodarca nastol'uje v prípade, ak obvinený navrhuje na hlavnom pojednávaní vypočut' svedkov, ktorých výpoved’ navrhol prokurátor v obžalobe iba prečítat'. V takomto prípade je obvinený povinný bez meškania, písomne oznámit' súdu návrh na vykonanie osobného výsluchu predmetných svedkov (porov. \240 ods. 3 Trestného poriadku). Zákonodarca, pre tento prípad, teda $\mathrm{v}$ prípade, že obvinený bez meškania (v primeranej lehote stanovenej konajúcim súdom) nenavrhne osobný výsluch takéhoto svedka, stanovuje rigorózne procesné konzekvencie vo forme možnosti konajúceho súdu, na hlavnom pojednávaní prečítat' zápisnicu o výsluchu, aj bez súhlasu obvineného (obžalovaného) za podmienok ustanovených v \ 263 ods. 2 Trestného poriadku. 
Korekciu, deklarovaných procesných následkov spojených s nevyužitím priznaných procesných práv, predstavuje ust. 240 ods. 3, posledná veta za prostredníkom, Trestného poriadku, ked’ zákonodarca ustanovuje výluku z deklarovaných procesných následkov účinkov, v prípade, ak nastala nová okolnost', ktorá nebola obvinenému známa, v čase doručenia výzvy.

Zákonodarca, v ust. \240 ods. 4 Trestného poriadku, koncipuje d’alšiu výnimku zo zásady jednotnosti konania, a teda atribút koncentračnej zásady aj ked’ iným spôsobom, ako tomu bolo v prezentovaných procesných situáciách, normatívne vyjadrených v ust. \240 ods. 3 Trestného poriadku, ked’ explicitne stanovuje obsahové náležitosti, návrhu na vykonanie dôkazov, predložených v intenciách ods. 3.

V zmysle ust. \ 240 ods. 4 Trestného poriadku „v návrhu na vykonanie dôkazov, podl’a odseku 3, treba uviest' okolnosti, ktoré sa majú nimi objasnit', a ak ide o svedka, treba uviest' aj skutočnosti, na ktoré má byt' vypočutý. Dôkazy musia byt' označené tak, aby ich bolo možné na hlavnom pojednávaní vykonat', okrem prípadov, ked' vykonanie dôkazu zabezpečí ten, kto jeho vykonanie navrhol. Ak sa navrhuje výsluch svedka alebo znalca a navrhovatel' oznámi, že nemôže zabezpečit' jeho prítomnost' na hlavnom pojednávaní a žiada preto súd o jeho predvolanie, treba uviest' údaje o jeho totožnost' a bydlisko, inak súd vykonanie tohto dôkazu spravidla odmietne.

Z citovaného ustanovenia \240 ods. 4 Trestného poriadku, vyplýva, že zákonodarca, nesplnenie ustanovenej procesnej povinnosti dotknutou procesnou stranou, postihuje procesným následkom, vo forme možnosti konajúceho súdu, takýto dôkaz odmietnut’.

V konečnom dôsledku atribút koncentračnej zásady, nachádzame aj v ust. \ 240 ods. 5 'Trestného poriadku, ked' zákonodarca ustanovuje povinnost' prokurátorovi a obvinenému, aby v prípade, že navrhujú na hlavnom pojednávaní, vypočut' svedkov a znalcom, navzájom si oznámili tieto procesné návrhy, najneskôr tri pracovné dni pred hlavným pojednávaním, pokial' tieto skutočnosti neboli oznámené v obžalobe alebo pri predbežnom prejednaní obžaloby.

Pre prípad nesplnenia avizovanej procesnej povinnosti prokurátorom, či obvineným, zákonodarca spája procesné konzekvencie, vo forme možnosti zrealizovat' výsluch uvedených subjektov, len v prípade, ak prokurátor a obvinený s tým súhlasia.

V tejto súvislosti sa žiada pripomenút', že predmetné cit. ust. \ 240 ods. 1-5 Tr. poriadku, predstavuje normatívne vyjadrenie koncentračnej zásady, a to vo forme sudcovskej koncentrácie konania, ked’ zákonodarca ponecháva na subjektívnej autonómnej úvahe konajúceho súdu, či odmietne vykonat' oneskorene navrhnutý dôkaz, a teda či pri svojom meritórnom rozhodovaní bude na ne prihliadat'.

V nadväznosti na predmetné ust. \240 ods. 1-5 Tr. por., zákonodarca neposkytuje konajúcemu súdu žiaden procesný manuál, ako má postupovat' pri uplatňovaní tohto 
koncentračného imperatívu, a to ani príkladmo, ako je tomu v prípade ust. \153 ods. 1 veta druhá C.s.p.

Jednoducho rozhodovanie o tom, v ktorých procesných situáciách, konajúci súd uplatní priznanú sudcovskú koncentráciu, zákonodarca ponecháva na subjektívnej sudcovskej úvahe, čo vytvára stav právnej neistoty pre dotknuté procesné subjekty, ktoré za týchto okolností nedokážu objektívne predvídat', ako konajúci súd v konkrétnom prípade procesnej situácii, bude postupovat'.

Nič na veci nemení skutočnost', že konajúci súd, v určitých prípadoch môže na skutočnost', či procesnej strane bol známy dôkaz už v čase doručenia výzvy na doplnenie dokazovania, usudzovat' na základe charakteru dôkazu, osobitne ak taký dôkaz má charakter listinného dôkazu.

Napriek uvedenému, popísaný normatívny stav, de lege lata, vytvára viaceré interpretačné a aplikačné problémy, pri uplatňovaní avizovanej sudcovskej koncentrácie, medzi koncentračnou zásadou a zásadou zistenia skutkového stavu veci bez dôvodných pochybností, ako aj zásadou prezumpcie neviny a z nej vyplývajúceho procesného pravidla in dubio pro reo.

Za tohto stavu, uplatnenie koncentračnej zásady (sudcovskej koncentrácie), normatívne upravenej v ust. \ 240 ods. 1-5 Tr. por., neprichádza do úvahy. Jednoducho neprichádza do úvahy uplatnenie sudcovskej koncentrácie, v procesnej situácii, ked’ objektívne existujú aj d’alšie dôkazy, ktoré môžu prispiet' k náležitému objasneniu skutkového stavu veci, a to aj napriek tomu, že procesná strana tieto navrhla vykonat' oneskorene (tzv. polehotné dôkazy).

Prípadné uplatnenie sudcovskej koncentrácie, za týchto okolností, zakladá kolíziu (konkurenciu) medzi koncentračnou zásadou a zásadou náležitého zistenia skutkového stavu veci, ako aj zásadou prezumpcie neviny a z nej vyplývajúceho procesného pravidla in dubio pro reo, ktorú je nevyhnutné riešit' v prospech zásady náležitého zistenia skutkového stavu veci a zásady prezumpcie neviny.

Konajúci súd totiž nemôže rozhodnút' oslobodzujúcim rozsudkom, podl'a ust. \ 285 písm. a), c) Tr. por., pokial' v predmetnej veci, objektívne existujú aj d’alšie doposial' nevykonané dôkazy, o ktorých má vedomost', a ktoré môžu prispiet’ k náležitému zisteniu skutkovému stavu veci, nakol'ko takýto procesný postup, by odporoval materiálnej podstate zásady prezumpcie neviny a z nej vyplývajúceho procesného pravidla in dubio pro reo, ako aj zásade náležitého zistenia skutkového stavu veci.

Princíp prezumpcie neviny a z neho vyplývajúce procesné pravidlo in dubio pro reo, možno pri meritórnom rozhodovaní uplatnit' len $\mathrm{v}$ tom prípade, ak pretrvávajúce dôvodné pochybnosti, o skutkovej otázke, nemožno odstránit' ani vykonaním d’alších dostupných dôkazov, čomu zodpovedajú dôvody oslobodenia spod obžaloby podl’a ust. \285 písm. a), c) Tr. poriadku. 
Rovnako zásada náležitého zistenia skutkového stavu veci, nastol’uje procesnú požiadavku, aby konajúci súd nielen vykonal ale rovnako tak obstaral všetky dôkazy, ktoré môžu prispiet' $\mathrm{k}$ náležitému zisteniu skutkového stavu veci, čo v konečnom dôsledku umožňuje spravodlivé rozhodnutie - spravodlivé potrestanie páchatelov, a tým aj naplnenie základného účelu trestného konania, deklarovaného v ust. $\int 1$ Tr. poriadku.

Inak povedané, v rozpore so zásadou náležitého zistenia skutkového stavu veci, by bol postup konajúceho súdu, ktorý by v dôsledku aplikácie koncentračnej zásady, nevykonal niektoré dôkazy významné pre zistenie skutočnosti významných z hl'adiska naplnenia zákonných znakov trestného činu.

Jednoducho ani prípadná procesná pasivita procesných strán, osobitne obžalovaného, pri navrhovaní dôkazov, neodôvodňuje a nelegitimizuje procesný postup konajúceho súdu, ktorým odmietne oneskorene navrhnuté dôkazy.

Opačný postup, zakladá kasačný dôvod, podl’a \321 ods. 1 písm. c) Tr. por., na rozhodnutie odvolacieho súdu o zrušení takéhoto rozhodnutia, a to vzhl'adom na existenciu pochybnosti o správnosti skutkových zistení, na objasnenie ktorých treba dôkazy opakovat', resp. vykonat' d’alšie dôkazy.

Z uvedených dôvodov, konajúce súdy, v aplikačnej praxi, pristupujú k uplatňovaniu avizovanej sudcovskej koncentrácii, vel'mi obozretne, vedomí si možných procesných konzekvencií s tým spojených.

Za týchto okolností potom vyvstáva absolútne legitímna otázka, či predmetné ust. \240 ods. 1-5 Tr. por., reglementujúce procesné podmienky uplatnenia sudcovskej koncentrácie, nenadobúda obsoléntny charakter, a teda nie je samoúčelné.

Z prezentovaného prehl'adu procesných konzekvencií, ktoré zákonodarca spája s nesplnením deklarovaných procesných povinností dotknutými procesnými stranami vyplýva, že tieto koncipuje ako podmienene konzekvencie. Podmienenost' procesných konzekvencií objektívne zoslabuje reálny účinok jednotlivých normatívnych atribútov koncentračnej zásady, a to $\mathrm{v}$ prospech naplnenia zásady zistenia skutkového stavu bez dôvodných pochybností. Zároveň sa tým zoslabuje elektorát procesných prostriedkov naplnenia zásady kontradiktórnosti súdneho konania, rovnosti konania a $\mathrm{v}$ neposlednom rade aj zásady rýchlosti a hospodárnosti (efektivity). Z uvedeného teda vyplýva, že zásada zistenia skutkového stavu veci bez dôvodných pochybností nadobúda favorizovaný status „hlavnej“ základnej zásady trestného konania, na úkor ostaných zmieňovaných základných zásad trestného konania. 


\section{Vzt’ah koncentračnej zásady a referenčných zásad trestného konania}

\subsection{Vzt'ah koncentračnej zásady a zásady zistenia skutkového stavu bez dôvodných pochybností}

Status a význam zásady zistenia skutkového stavu bez dôvodných pochybností sa v trestnom konaní, odvíja od účelu trestného konania, ktorý je normatívne reglementovaný v ust. $\int 1$ Trestného poriadku. Účelom trestného konania je primárne zabezpečit', aby trestné činy boli náležite zistené a ich páchatelia podl’a zákona spravodlivo potrestaní.

Následne zákonodarca význam a status zásady zistenia skutkového stavu bez dôvodných pochybností potvrdil a akcentoval aj v ust. \2 ods. 10 Trestného poriadku, ked' ustanovuje, že „orgány činné v trestnom konani postupujú tak, aby bol zistený skutkový stav veci, o ktorom nie sú dôvodné pochybnosti."

K uvedenému sa žiada poznamenat', že zákonodarca pojmový znak (kritérium) „dôvodná pochybnost"“, ktorú využíva pri normatívnej reglementácii predmetnej základnej zásady, nijako bližšie neprecizuje, ani nevysvetl'uje.

Za „dôvodnú pochybnost'“, možno považovat' pochybnost', ktorá by spôsobila, že súd (či orgány činné v trestnom konanî), po starostlivom objektívnom a nestrannom zhodnotení všetkých dostupných dôkazov, by bol tak nerozhodný, že by nemohol povedat', že uvedená skutočnost' napĺñajúca znak trestného činu, sa stala, a teda by nemohol povedat', že získal ustálené presvedčenie o vine obžalovaného (obvineného). Nie je to však imaginárna pochybnost', ani pochybnost' založená na rozmare alebo určitej náhode, či na domnienke alebo dohadu. ${ }^{18}$

Dôvodné pochybnosti sa vzt'ahujú tak k zisteniu vlastného skutkového stavu, tak k prípadnej možnosti obstarat' d’alšie dôkazy, ktoré by doterajší výsledok dokazovania zmenili alebo zvrátili.

V rozpore so zásadou náležitého zistenia skutkového stavu veci, by bol postup orgánov činných $\mathrm{v}$ trestnom konaní, ktorí by v prípravnom konaní, pod vplyvom nesprávnej aplikácie zásady in dubio pro reo, nevykonali čast' dôkazov významných pre zistenie skutočností rozhodujúcich z hl'adiska zákonných znakov trestného činu s tým, že skutočnosti, na objasnenie ktorých mali smerovat' nevykonané dôkazy, prokurátor následne v podanej obžalobe neuplatnil.

Trestný poriadok ustanovuje, že primárnym ciel’om zásady náležitého zistenia skutkového stavu veci, je umožnit' súdu spravodlivé rozhodnutie. ${ }^{19}$

18 ŠÁMAL, P. Základní zásady trestního rízenív demokeratickém systému. Praha: SEVT, a. s., 1995, s. 185. Př́ručky Ministerstva spravedlnosti ČR, Svazek 53.

19 MINÁRIK, Š. a kol. Trestný poriadok - stručný komentár. Bratislava: IURA EDITION, 2006, s. 39. 
Z uvedeného vyplýva, že zákonodarca zásade zistenia skutkového stavu vec bez dôvodných pochybností, priznáva status hlavnej zásady trestného konania, ktorá podstatným spôsobom podmieňuje a ovplyvňuje spôsob a rozsah uplatnenia ostatných zásad trestného konania. Spôsob a rozsah uplatnenia koncentračnej zásady v trestnom konaní, ako aj jej vzt’ah k zásade zistenia skutkového stavu bez dôvodných pochybností, zákonodarca normatívne vyjadril v ust. \240 ods. 3 Trestného poriadku. V tejto súvislosti sa žiada poznamenat', že tento vzt'ah, zákonodarca celkom jednoznačne rieši v prospech zásady zistenia skutkového stavu bez dôvodných pochybností, čo možno nepriamo dedukovat' z možnosti, ktorú priznáva konajúcemu súdu, modifikovat’ koncentrované procesné povinnosti procesných strán, ktoré im ust. \240 ods. 3-5 Trestného poriadku, ukladá. Priamo je možné túto súvzt’ažnost' medzi predmetnými zásadami, dedukovat' z dikcie ust. \321 ods. 1 písm. c) Trestného poriadku, kde zákonodarca reglementuje dôvod kasačného rozhodnutia súdu I. stupňa, spočívajúceho v pochybnostiach týkajúcich sa správnosti skutkových zistení.

\subsection{Vzt’ah koncentračnej zásady a zásady kontradiktórnosti, zásady rýchlosti trestného konania}

Vzt’ah koncentračnej zásady a zásady zistenia skutkového stavu dôvodných pochybností, vel'mi úzko súvisí so zásadou kontradiktórnosti.

Zásada zistenia skutkového stavu bez dôvodných pochybností, vymedzuje mantinely, limity, v ktorých sa tak koncentračná zásada, ako aj zásada kontradiktórnosti či rýchlosti trestného konania, môžu uplatnit' a rozvinút'.

Kontradiktórnost' je dlhodobo považovaná za právny princíp, za pravidlo prirodzeného práva.

V Slovenskom Trestnom poriadku, hoci nie je explicitne obsiahnutá, je zakotvená medzi základnými zásadami trestného konania v ust. \2 ods. 7 („každý má právo, aby jeho trestná vec bola spravodlivo a v primeranej lehote prejednaná nezávislým a nestranným súdom a v jeho prítomnosti tak, aby sa mohol vyjadrit' ku všetkým vykonávaným dôkazom, ak tento zákon neustanovuje inak“') a v odseku 18 druhá veta Trestného poriadku („dokazovanie riadi súd, ktorý však výsluch obžalovaného, svedkov, poškodeného a znalcov spravidla ponecháva stranám, najprv tej, ktorá dôkaz navrhla, či obstarala“).

Aj napriek uvedenému zásada kontradiktórnosti neslúži len stranám vo forme ich zabezpečeného práva na obhajobu, ale je zároveň metódou hl’adania pravdy a kritériom súdneho procesu. ${ }^{20}$

Kontradiktórnost' je v dikcii slovenských základných zásad trestného procesu, výlučne spájaná s oblast'ou dokazovania.

20 OLEJ, J., M. KOLCUNOVÁ a J. KOLCUN. Kontradiktórnost'v trestnom konaní. Bratislava: C. H. BECK, 2014, s. 69. 
Kontradiktórnost' sa skladá z dvoch zložiek:

a) z práva oboznámit' sa so všetkými dokumentmi a dôkazmi, ktoré môžu ovplyvnit' rozhodnutie (právo na informácie);

b) z možnosti vyjadrit' sa k predloženým materiálom a dôkazom.

Kontradiktórnost' vnímaná vo všeobecnosti aj ako spor procesných strán, stavia konajúci súd do procesnej pozície nezávislého arbitra, ktorého úlohou je nestranne a spravodlivo rozhodnút' tento spor, na základe výsledkov procesnej aktivity súperiacich procesných strán.

V uvedenom kontexte vyvstávajú synergické procesné požiadavky a konzekvencie, na projekciu tohto princípu do normatívnej úpravy konkrétnych procesných opatrení (inštitútov). Zároveň sa tým vytvára priestor pre uplatňovanie, resp. rozvinutie d’alších procesných zásad akými je aj zásada koncentračná. Jednoducho jednotlivé atribúty prvky koncentračnej zásady, implementované do normatívnej úpravy podmienok dokazovania v súdnom konaní, predstavujú konkrétny spôsob a formu aplikačného uplatnenia zásady kontradiktórnosti.

Nepochybne ciel'om všetkých moderných trestnoprocesných kódexov je urýchlit' a zefektívnit' priebeh trestného konania. K limitom uplatnenia, tak zásady rýchlosti, ako koncentračnej zásady, v trestnom konaní, a to vo vzt’ahu k zásade zistenia skutkového stavu bez dôvodných pochybností, sa celkom výstižne a presvedčivo vyjadril J. KLÁTIK, ktorý v tejto súvislosti poznamenáva, že „,prostriedky, ketoré umožnujujú urýchlené trestné konanie, by sa mali pouřit' len vtedy, kedy by bolo na základe starostlivébo a nestranného zhodnotenia dôkazov jednoznačné, že skutok napína skutkovú podstatu trestnébo činu a spáchala ho konkrétna osoba“. ${ }^{21}$ K uvedenému J. IVOR dodáva, že „rýchlost’ konania však nie je a ani nemôže byt' absolútnou hodnotou, musi byt' podriadená vy̌šsiemu princípu spravodlivosti, ktorý by mohol byt' obrozený prílišnou uponábl'anost'ou konania. Každý skutok musi byt' objasnený, aby nedošlo k dôvodným pochybnostiam o existencii trestného činu, osobe páchatel'a a d'alšich znakov určujúcich skutok ako trestný čin. Rýchle prejednanie veci je $v$ tomto kontexte iba naplnenim vybavenia trestnej veci v primeranej lehote ".22

$\mathrm{V}$ koncentrovanej forme sa k uplatňovaniu zásady prejednania veci v primeranej lehote, normatívne vyjadrenej v ust. \ 2 poznamenal, že ,pomalá spravodlivost'sa považuje za odmietnutú spravodlivost' a príliš rýchle roz̧hodovanie za prenáblenost".

\section{Záver}

Koncentračná zásada napriek tomu, že je vo svojej podstate vlastná predovšetkým civilnému konaniu, pričom ideovo vel’mi úzko súvisí so zásadou formálnej pravdy, de lege lata, a možno vyslovit' presvedčenie, že aj de lege ferenda, nájde svoje uplatnenie v rámci

21 KLÁTIK, J. Zrýchlenie a z̧hospodárnenie trestného konania. Banská Bystrica: Univerzita Mateja Bela, Právnická fakulta, 2010, s. 11.

22 IVOR, J. a kol. Trestni právo procesné. Bratislava: IURA Edition, 2007, s. 63. 
trestného konania. Predmetom úvah, polemík a diskusií, nepochybne bude spôsob a rozsah uplatnenia jej vplyvu v trestnom konaní.

De lege ferenda, limitom - maximom pre uplatnenie koncentračnej zásady v trestnom konaní, je naplnenie účelu sledovaného trestným konaním, ktorý je celkom jednoznačne a explicitne normatívne upravený v ust. \1 Trestného poriadku, spočívajúci v náležitom zistení trestných činov a spravodlivom potrestaní ich páchatel’ov. Samozrejme pri rešpektovaní ostatných základných zásad a princípov trestného konania, predovšetkým zásady rýchlosti a kontradiktórnosti trestného konania, ktoré predstavujú významné atribúty spravodlivého konania. Ciel'om uplatnenia a kreovania koncentračnej zásady v trestnom konaní, by mala byt' úprimná snaha zákonodarcu, vytvorit' účinný mechanizmus procesných záruk a opatrení, ktoré by vo svojich dôsledkoch, eliminovali účelové a obštrukčné konanie procesných strán, pri uplatňovaní ich procesných práv, osobitne procesných práv súvisiacich s procesom dokazovania. 